This item was submitted to Loughborough's Research Repository by the author.

Items in Figshare are protected by copyright, with all rights reserved, unless otherwise indicated.

\title{
Political actors, public opinion and the extension of welfare coverage
}

PLEASE CITE THE PUBLISHED VERSION

PUBLISHER

SAGE Publications

VERSION

AM (Accepted Manuscript)

\section{PUBLISHER STATEMENT}

Kevins, A., Political actors, public opinion and the extension of welfare coverage, Journal of European Social Policy (25:3) pp. 303-315. Copyright @ 2015 (The Author). DOI: 10.1177/0958928715588705. Users who receive access to an article through a repository are reminded that the article is protected by copyright and reuse is restricted to non-commercial and no derivative uses. Users may also download and save a local copy of an article accessed in an institutional repository for the user's personal reference.

\section{LICENCE}

CC BY-NC-ND 4.0

\section{REPOSITORY RECORD}

Kevins, Anthony. 2019. "Political Actors, Public Opinion and the Extension of Welfare Coverage". figshare. https://hdl.handle.net/2134/9976259.v1. 
Political Actors, Public Opinion, and the Extension of Welfare Coverage:

Benefits for the Unemployed in France, Italy, and Beyond

Anthony Kevins

(Aarhus University)

Published in the Journal of European Social Policy: doi.org/10.1177/0958928715588705

Abstract: In a post-industrial world in which employment is increasingly "non-standard", the tying of benefit access to standard employment history in insurance-style programmes has created considerable insider-outsider welfare state divisions. This paper investigates the factors shaping attempts to address this issue through the extension of benefit coverage. Comparing the introduction of minimum income schemes in France and Italy, it explores the explanatory power of various partisanship- and institution-based accounts. The paper argues that Italian inaction was the result not of partisanship-based factors, but rather of contrasting levels of public pressure. The divergent public opinion was, in turn, shaped by institutional characteristics typically associated with Southern European welfare states. Survey and multilevel model analyses provide support for the claim that the centrality of the family and limited administrative capacity have impacted concern for the unemployed.

Keywords France, Italy, Southern European welfare states, outsiders, welfare state reform, minimum income schemes 
Given that access to unemployment insurance is tied to labour market history, it has been especially susceptible to developments in the labour market. In particular, financial stresses and the growing number of atypical employees (a group that is generally unable to qualify for unemployment insurance) over the past several decades have compromised coverage rates. As a result, social assistance has become increasingly essential in preventing large swaths of unemployed persons from falling through gaps in protection. Yet in many countries where the insurance principle has historically occupied a central role across welfare state institutions, these programmes were either introduced relatively recently or are still absent.

Exploring this process of coverage extension via social assistance, this paper will contrast the French and Italian experiences surrounding the introduction of a national minimum income scheme - a benefit of last resort designed to combat poverty and target all unemployed persons (rather than simply those who had made adequate unemployment insurance contributions). The goal here is to explore, using existing research, insights from interviews with party and union officials, and survey analysis, why substantial gaps in coverage have been filled in some countries but persist in others.

In examining the contrasting fates of the minimum income benefits (and the divergent outcomes vis-à-vis welfare state outsiders that that implies), we consider explanations stressing both partisanship and institutional characteristics. To preview our conclusions, it will be argued that the different trajectories in France and Italy do not reflect any consistent relationship between partisanship and benefit extension. Rather, the divergent outcomes in the cases are argued to be the consequences of contrasting levels of public pressure, with relevant public preferences shaped by institutional factors. These conclusions are then tested cross-nationally using multi-level model analysis of 12 European countries, and evidence suggests that most of the same dynamics may also be at play elsewhere. 
Using Ferrera's (2005) work on social assistance in Southern European welfare states as our framework, a case will be made for the importance of two Southern European characteristics in particular: namely, the centrality of the family in the Italian welfare state and limited administrative capacity. In short, we argue that the availability of alternative sources of assistance mitigates support for state intervention, both at the individual- and aggregate-level. The analysis presented below will suggest that these Southern European traits can help us understand why Italy has been unable to follow in France's footsteps, more than two decades after France introduced universally available benefits for the unemployed.

\section{A Contextualizing the Cases}

Our comparison of these two cases is predicated on both certain key general attributes and the contrasting fates of a particular social assistance programme. While France and Italy can both be considered somewhat atypical corporatist states, Italy's system is much more fragmented, traditional (particularly regarding gender roles and the family), and clientelistic, leading many to categorize it as specifically Southern European (cf. Ferrera, 1996; Naldini, 2003). Yet the countries do share two particular traits that are central for our broader purposes: an insurance-centred focus that has led to a certain degree of rationing through occupational and contribution-based controls on who has access to benefits; and a general, historical inadequacy of social assistance benefits (with actual programmes both means-tested and categorical, requiring recipients to belong to a protected category of individuals (e.g. the disabled)), thereby failing to fill in most of the gaps in unemployment insurance.(1) The structure of these systems meant that as unemployment and atypical employment expanded, so too did the number of individuals without access to benefits (i.e. welfare state outsiders).

In France, the country's late development of social assistance placed the system more in line with Southern European welfare states than other Continental ones (Paugam, 1993: 23). 
But although successive French governments initially dealt with coverage issues through ad hoc extension to certain categories of unprotected groups, they eventually moved past this approach - particularly with the 1988 introduction of a minimum income scheme ( Minimum d'Insertion). This marked a substantive shift from the old approach toward social assistance benefits; unemployment under this new characterization was not simply a risk, but also a potential status, entitling one to access benefits unrelated to insurance contributions (Paugam, 1993: 105; Barbier and Théret, 2001, 156). The end result has been an expansion of the social safety net in France, "stemming the rise of inequality and poverty through policies that compensate for trends unfolding in the market... guarantee[ing] that nobody can be left without any support" (Palier and Thelen, 2010: 138-139).

Italy, on the other hand, experimented with its own minimum income scheme ten years

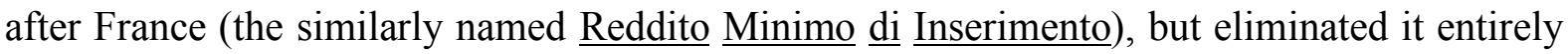
within a few years. The end result is an Italian system with comparatively low coverage, as well as the vast discrepancies in benefit generosity that entails - with an $80 \%$ replacement rate for some and $0 \%$ for many others. This failure to enact more substantial reforms is, in turn, reflected in Italy's abysmal record of using transfers to reduce poverty (see Fargion, 2003: 336).

\section{A Politics and the Minimum Income Schemes}

The comparison of France and Italy is also of interest in light of the contrasting role of partisanship in the two cases. As a result, it provides a useful addition to recent studies investigating the relationship between parties and outsiders (e.g. Garrett, 1998; Rueda, 2007; Davidsson and Emmenegger, 2012). The politics behind the creation of the French and Italian minimum income programmes, however, provides little evidence of a consistent partisan relationship to pro-outsider reform. 
In France, public concern regarding les $\underline{\text { exclus }-i . e . ~ u n e m p l o y e d ~ i n d i v i d u a l s ~ w h o s e ~}$ integration into the labour market and society have been compromised by poverty and other barriers - made benefit reform a salient political issue. Conceptions of egalitarianism in France during the 1970s gradually shifted away from a concern with equality of benefits and toward a correction of what would otherwise be vast inequalities in access to benefits (Bec, 1995: 138). With rising unemployment a serious problem by the 1980s, integration of les exclus had become a major issue in public debate as both the left and right criticized the government over the rise of the "new poor" (Paugam, 1993: 66; Béland and Hansen, 2000: 55). In particular, youth and banlieue unemployment increasingly became a central fixture of the debate as young people partook in a series of demonstrations against various reforms (Silver, 1994: 533-534). High long-term unemployment rates and increasingly common atypical employment further complicated the situation.

Despite some initial tentativeness (Belorgey, 1988: 105-106), it was in this context that Mitterrand's 1988 campaign promise to introduce a minimum income programme came about (see Mitterrand, 1988). Popular concern about the issue was clearly substantial enough for Mitterrand to use the issue to try to tap into traditional Parti Communiste Français voters and mobilize the left-wing of the electorate (Clegg, 2010: 91). At the same time, the programme was popular enough for it to pass quasi-unanimously in the National Assembly (albeit with the assistance of the reform's vagueness (Palier, 2004: 118-119)) and to prevent subsequent governments on the centre-right from eliminating it (although it has been retooled, most notably with its replacement by the Revenu de solidarite active). This ongoing bipartisan popularity raises questions about any kind of straightforward relationship between partisanship and reform more generally. 
The Italian minimum income programme, in turn, also came about in the context of growing unemployment and atypical employment. In light of this picture, one would assume that, all else being equal, the clamour for the scheme should have been substantial.

Yet the creation of the Italian minimum income programme in 1998 lacked both party backing on the right and the kind of public support that would have led to outrage at its dismantling in 2002. In the end, in fact, it is difficult to explain the experiment without reference to the influence of external factors relating to the European Union. As Graziano and Jessoula argue, the programme's creation was the result of two factors: first, European cognitive resources (specifically vis-à-vis policy ideas) and comparisons to other member states resulted in increased debate about gaps in the Italian welfare state, while also providing potential solutions to resolve them; second, the Prodi government attempted to use this opening, as well as claims about external constraints, to build a pro-reform coalition (2011, 164). Yet this approach lost much of its efficacy once Italy had met the Maastricht requirements and pressures from the EU subsided - not least of all because divisions within the left coalition and between it and the unions became increasingly difficult to manage (Fargion, 2003: 335).

And although leftist Italian parties do appear to be rather consistently in favour of a minimum income benefit there has been little advancement on the issue, including during the left coalition's returns to power.(2) This may partly be explained by the opposition of most of the major union confederations; two of the three largest union confederations signed the 2002 "Pact for Italy" that argued that the experiment had demonstrated "the impracticality of using a State law to determine who has a right to [assistance]" (Accordo Interconfederale, 2002: 7 [my translation]).(3) Broad public support for the reintroduction of the programme might have counteracted these pressures, but movements of the type seen in France were largely lacking.

Given that the push toward major reform of the Italian unemployment benefit system seems to have been driven more by external factors than internal pressures for reform, the 
contrast with the French case suggests that certain non-partisanship based determinants of benefit extension may be missing in Italy. Although leftist Italian parties continue to appear open to the creation of a minimum income programme, their failure to prioritize the issue while in government raises questions about a consistent relationship to extension. This situation contradicts that in France, where the scheme has enjoyed bipartisan support. As a result, partisanship cannot explain the divergence. Instead, we argue that the key difference centres around demand for reform.

\section{A Southern European Characteristics And Public Pressure}

Both Italy and France have experienced considerable pressure on their unemployment insurance systems, yet only in France do we see a forceful public debate about the nature of the benefit system and the strategic use of the issue for electoral purposes. Since there is certainly not a dearth of welfare state outsiders in Italy - recent estimates suggest that approximately $19 \%$ of part-time workers with a permanent contract, $38 \%$ of workers with fixed-term full-time contracts, and $48 \%$ of full-time temp-agency workers completely lack access to benefits in cases of unemployment (Berton et al., 2009: 55) - some other factor(s) must explain the divergent outcomes.

[Figure 1 about here]

Figure 1 provides an illustration of this apparent disjuncture over time - albeit somewhat crudely, given that there are only three data points from the ISSP with which to work. The graph tracks Italian attitudes about government responsibility to provide for the unemployed alongside the prevalence of (probable) Italian welfare state outsiders. Respondents were asked "on the whole, do you think it should or should not be the government's 
responsibility to provide a decent standard of living for the unemployed", with four potential responses ranging from "definitely should be" to "definitely should not be". Decreasing agreement with this statement(4) contrasts with the increasing numbers of probable welfare state outsiders over the same period (calculated as the summed proportion of the self-employed, part-time workers, temporary workers, and the long-term unemployed).(5) Since one would assume that outsiders would be pro-government responsibility, either the population at large changed their minds to such an extent that they more than compensated for this shift, or outsiders did not adjust their attitudes as one would expect (or, indeed, both may have happened).

A focus on institutions helps resolve this contradiction by highlighting how an increase in the number of persons without access to benefits might fail to correspond with increasing concern for the wellbeing of the unemployed. Southern European characteristics are a particularly likely explanatory candidate, given that a lack of social assistance is presented as one of the common features of these systems (Ferrera, 1996: 20). In particular, Ferrera highlights three factors in his discussion of the delay and/or lack of development of assistance benefits in Southern Europe: administrative difficulties; the size of the informal economy; the greater role of the family $(2005,8-10)$. Implicit in this approach is the argument that outsiders (under certain circumstances) may actually come to support policies that fail to protect them; indeed, this position has found some support in work on labour market policies (Emmenegger, 2009). This approach therefore highlights circumstances that might lead outsiders to variously support or oppose reform of systems that seemingly ignore their needs.

To begin, lower-level administrative difficulties, which lead to both fears of clientelistic behaviour on the part of local administrators and a restricted capacity to determine legitimate benefit recipients, have undoubtedly impeded the development of means-tested benefits in Southern Europe (Ferrera, 2005: 10; Dell'Aringa and Lodovici, 1996: 182). This is of particular 
concern given the well-known lack of administrative capacity in certain Italian regions and the contrast with France that this highlights (cf. Putnam, 1993; Milio, 2007).

The minimum income scheme experience partially confirms this, with the Berlusconi government referring to local governments" "lack of capacity in designing and implementing social insertion measures" as one of the central problems with the experiment (Ministero del Lavoro e delle Politiche Sociali, 2003: 27-28 [my translation]). But rather than suggesting a complete lack of competency or capacity on the part of municipal governments, many of the concrete problems that arose had practical, workable solutions that did not necessarily require inordinately greater administrative capacity (see Sacchi and Bastagli, 2005: 122-124). Given that such changes need not have been revolutionary, there is limited reason to assume that administrative limitations have doomed Italian minimum income schemes from the start. Instead, we would stress the ways in which popular belief in the challenges posed by administrative issues could lead to scepticism vis-à-vis the feasibility of such a benefit (despite the apparent belief among politicians that they can in fact be addressed).(6)

Along similar lines, the prevalence of work in the informal economy has arguably created an environment in which the actual employment status of a formally unemployed worker is easily called into question (Ferrera, 2005: 9; Gough, 1996: 15). One can easily understand how this factor could contribute to a lack of sympathy for unemployed persons without recourse to benefits, while at the same time creating administrative difficulties regarding the determination of eligibility. Although it is difficult to measure the informal economy, Italy is widely regarded as having one of the largest in the OECD, with Schneider estimating that it represents $26.2 \%$ of the country' s GDP (compared with $14.8 \%$ in France and an OECD average of 16.4\%) (2005: 611).(7) Given these circumstances, Italians may understandably believe that so-called unemployed persons are actually working under the table. What is more, those nominally "unemployed" individuals working in the informal labour 
market will presumably be far less concerned about support for the unemployed than the truly unemployed.

Arguably even more important is the family-centred nature of Southern European welfare states such as Italy's, with state protection concentrated on the risks that the family cannot deal with by themselves (Gough, 1996: 14; Matsaganis et al., 2003: 642; Ferrera, 2005: 8). This approach has been made possible by the persistent strength of the family, which has insulated adult children from risk. This is an especially important phenomenon since Italian youth (and particularly young women) are more likely to be unemployed or in atypical, unstable employment - leading to a substantial generational division in benefit coverage (Barbier and Fargion, 2004: 455). These circumstances at least partially help to explain why Italian youth are considerably more likely than youth in France (and indeed, in most Western countries) to remain at home later: constraining ourselves to the pre-crisis period, while in 2007 the average French woman moved out when she was 23 and the average French man at 24, the corresponding figures for Italy are 29 and 31 (Eurostat, 2009: 29).

The prediction here is that this ability to rely on the family affects the attitudes of (otherwise outsider) youth toward the unemployment benefit system. Indeed, evidence that consumption losses associated with unemployment spells have actually been lower in Italy and Spain than in the UK and Germany suggests that families may sometimes do more work for the unemployed than comparatively generous welfare states (Bentolila and Ichino, 2008). This is key since youths, dramatically overrepresented among the unemployed and atypically employed, offer a potential pressure point for reform - as was the case in France (see Silver, 1994: 533).

In light of the higher ages at which youth leave home in Italy, this family-based access to benefits should be of greater relevance than in France. What is more, to the extent that youth are considered prone to falling through the gaps in the unemployment system, popular concern 
is likely diminished by the belief that most of them can simply rely on their families. Since evidence suggests that outsiders have had limited occasion to influence reform decisions (see Baglioni et al., 2008), this general impact on attitudes may well be even more important than the influence on youths. The prevalence of the informal economy may serve a similar function, both with regard to the preferences of those working under the table and broader popular concern. In sum, these alternative sources of support likely reduce support for state intervention, both at the individual- and aggregate-level.

\section{A Examining Public Opinion}

Part of the expected impact of the factors highlighted above is the diminishment of popular dissatisfaction with the current benefit system, and this section will test the accuracy of the above picture using survey and multi-level model analysis. In examining the issue, we use the 1999 European Values Study, which took place a few months after the Italian minimum income experiment began. Our key question saw respondents asked to what extent they were concerned about the living conditions of unemployed persons, with potential answers ranging from "not at all" to "very much" (recoded from 0 to 1 in our analysis).

Table 1 presents the results of ordinary least squares regressions examining both Italian and French (weighted) survey data. Our key explanatory variable is 1 youths living in the parental home (defined as being 35 or under and living with at least one parent)(8). A variable for $\underline{2}$ youths living outside of the parental home is included in the analysis as well, to test for the possibility that what may really matter is being young (with the reference group being nonyouths).(9) We also include $\underline{3} \underline{\text { unemployment }}$ and $\underline{4}$ a variable measuring a belief in municipal administrative capacity, constructed using a question asking whether "more power to local authorities" is a good thing (with three possible responses - "bad thing" (coded 0), "don't mind" (coded 0.5), and "good thing" (coded 1). Building on models used by authors such as 
Blekesaune and Quadagno (2003) and van Oorschot (2006), other standard variables included are: $\underline{5}$ full-time employment (defined as working over 30 hours a week); 6 part-time

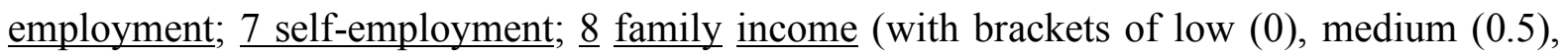
and high (1)); 9 gender; 10 education levels (with brackets of lower (0), middle (0.5), and upper (1)); and 11 being retired.

Looking first at Italian public opinion, results support our expectations and suggest that living with a parent has the predicted impact on the attitudes of youths. Findings suggest that living in the parental home is the major factor at work, tied to statistically significant decreases of just over 0.06 (out of a total range of 0 to 1 ). Whether through a lack of experience with true precariousness or due to indirect access to welfare state insider perks, residing with one's parents is associated with noticeably lower level of concern for the unemployed in Italy.

\section{[Table 1 about here]}

The only other variables in the model that achieve significance are related to employment status (in keeping with the results of Burgoon and Dekker (2010)). Both full-time employment and being self-employed are associated with decreases in concern for the

unemployed, with a statistically significant negative impact of about 0.04 and 0.05 respectively. While the former makes intuitive sense (given the group's greater access to benefits), the latter is somewhat unexpected. This may reflect the attitudinal dispositions prevalent among the sort of persons who start their own business, especially given that the category includes individuals who have employees. Regardless, there appear to be two clear routes to lowered concern for the unemployed: through employment status (i.e. being selfemployed or holding a full-time job) and being a young person living in the parental home. 
Turning to analyse French attitudes, more of the standard variables reach significance, with both unemployment and education associated with statistically significant increases in concern for the unemployed (while belief in municipal administrative capacity nears significance). Yet in this instance, living with one' $\mathrm{s}$ parents does not reach statistical significance (though the p-value, at 0.100 , almost nears significance). What is more, being a young person outside of the parental home is associated with lower levels of concern for the unemployed.

What explains the significance of youth outside of the parental home in this instance? Rather than there being something special about this particular group of youths, it is a function of the distribution of youth living arrangements across the countries: in France, as one would expect, a much larger proportion of youth in the sample live outside the parental home (at 77\%) than in the Italian case (at 39\%). As a result, in the French case the "youth outside of the parental home" category largely stands in for "youth". Conversely, the small number of observations within the category of "youth living with parents" at least partially explains why the variable only nears significance in France; although the coefficient is about the same as in the Italian model, the standard error is over twice as large.

Yet to properly assess the strength of our findings and assess generalizability, we must extend our investigation cross nationally across 12 European countries (listed in the Appendix) so as to examine survey responses in light of national-level data. In particular, in order to properly situate concern for the unemployed we must incorporate the extent to which the welfare state reduces poverty. This variable, 12 poverty reduction, is measured as the difference between pre- and post-transfer poverty rates (own calculation using Eurostat data (2012)). The two national-level variables that serve as our principal variables of interest are, in turn: $\underline{13}$ the

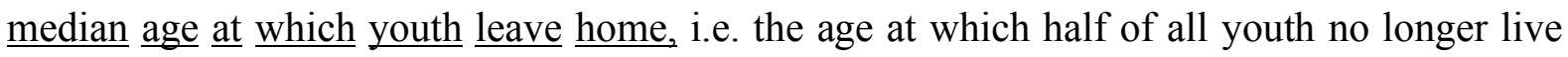
with their parents (for a discussion of the merits of this approach, see Iacovou, 2011: 2)(10) 
and $\underline{14}$ the size of the informal economy(11). Variables capturing interactions between poverty reduction and both home leaving and the informal economy are included in the analysis as well. The intuition here is that welfare states may moderate the impact of other variables and shape public opinion (see Brooks and Manza, 2007; Soroka and Wlezien, 2010), such that (for example) the median home leaving age may have a considerable impact where poverty reduction is low and a muted impact where poverty reduction is high.

In light of findings by authors such as Bonoli and Haüsermann (2009) and TaylorGooby (2011), we expect the standard variables already delineated above to be highly important. At the national-level, economic controls are also added for: $\underline{15}$ the mean unemployment rates over the past three years, to indicate the general labour market conditions (see Pfeifer, 2009); and 16 change in GDP per capita, to approximate recent economic performance.(12) Data for both variables are taken from the OECD (2012b; 2012c).

\section{[Table 2 about here]}

The results of the multi-level model analysis (using a generalized least squares randomeffects estimation) are presented in Table 2 . We build the model stepwise, first adding poverty reduction (the key policy component) into (Model 1), then the economic controls (Model 2), and finally our two variables of interest (Model 3). Despite the significance of many of the standard variables and theories in the literature, for our purposes, the most interesting results pertain to youth in the parental home, support for municipal power, median home leaving age, and the size of the informal economy. Results at the individual-level are fairly consistent across the models. Both being a young person inside the parental home and out of it have statistically significant impacts, with only a non-statistically significant difference between the coefficients. The interaction of being a young person living at home while also being 
unemployed initially adds an additional negative impact - but once controls are added the variable only nears statistical significance, dipping to the other side of the $\mathrm{p}=0.05$ marker (at 0.053 and 0.068 respectively). A belief in increasing municipal power, in turn, consistently has the predicted positive impact.

At the national-level, poverty reduction has the expected negative impact on concern for the unemployed, with a substantially larger coefficient when we control for our variables of interest. Mean unemployment also reaches statistical significance, and has the positive impact predicted by Pfeifer (2009). As for our variables of interest, higher home leaving ages are associated with decreases in concern for the unemployed, as suggested by the paired comparison - although (as anticipated) this effect is moderated in countries that already reduce poverty fairly well.

By contrast, the size of the informal economy, against our expectations, appears to be correlated with greater concern for the unemployed. Yet this result is driven entirely by Spain: dropping Spanish data removes the significance of the informal economy entirely. All other variables of interest remain unaffected to any notable degree, whether through the removal of Spanish data or data from any other specific country (see web appendix). Furthermore, these findings are not simply the result of correlations with important individual-level factors: neither the median home leaving age nor the size of the informal economy are particularly correlated with other variables associated with greater concern for the unemployed.(13)

On the whole, these results provide support for the importance of certain Southern European characteristics, both in Italy and more broadly. In the Italian context, although support for greater municipal power does not reach statistical significance, being a young person in the parental home is associated with a substantial decrease in concern for the unemployed. Analysis of French data does not reflect the Italian findings, but this is to be expected if poverty reduction levels matter vis-à-vis concern for the unemployed. This then 
leads us to test the theory cross-nationally, incorporating the national-level aspects of the hypothesis into the model. At the individual-level of the multi-level model, advocating the extension of municipal power is correlated with increased concern. The decreased concern for the unemployed found among youth in and out of the parental home is not statistically distinguishable, however, and the negative impact of being an unemployed youth living with one's parents only nears statistical significance. The former finding may reflect the differing make-up of the youth in the parental home across countries (with a higher proportion of postsecondary students outside of Southern Europe); the latter may relatedly be the result of limited respondents falling into this category in many countries (in the non-Southern European cases, there are ten or fewer respondents per country categorized as unemployed youth living in the parental home).

Nevertheless, late home-leaving ages are in fact associated with decreased concern for the unemployed within the broader population - although the impact is mitigated in countries with welfare states that are effective at poverty reduction. This moderating effect is to be expected insofar as welfare states that substantially reduce poverty reinforce themselves via public opinion and/or diminish popular attention paid to the neediness of unemployed youth. The apparent unimportance of the informal economy (once we exclude the Spanish case), by contrast, suggests that the variable may be less important than expected. Yet we hesitate to draw strong conclusions given the high correlation among our national-level variables: poverty reduction, the size of the informal economy, and median home leaving age are all correlated at rates between 0.73 and 0.87 . This complicates our ability to assess generalizability, but results nevertheless provide a good indication that certain findings from the French-Italian comparison may well be exportable to other contexts. 


\section{A Conclusion}

This paper has explored the contrasting fates of the French and Italian minimum income programmes in order to better understand the determinants of benefit extension to welfare state outsiders - specifically via residualization - within broader conditions of fiscal constraint. After providing brief background information on the cases, the paper proceeded to examine the factors surrounding the development of the respective minimum income schemes. There it was suggested that theories based on partisanship are unable to explain the divergence: while the French benefit developed primarily out of internal debate and concern regarding exclusion and enjoyed bipartisan support, the implementation of the Italian version was politically contested and driven by external factors related to the European Union (as evidenced by the left's failure to reintroduce the programme after regaining office). This contrast helps to explain why, after these factors subsided, the Italian scheme disappeared without much fanfare.

In order to explain this absence of internal pressure in Italy, it was than argued that certain characteristics of the Southern European welfare states, as highlighted by Ferrera (2005), diminish internal pressure for reform by decreasing the perceived precariousness of welfare state outsiders. In brief: the availability of alternative sources of support has reduced support for state intervention, both at the individual- and aggregate-level. The role of the family in particular is claimed to have pacified pressure from the young, who are disproportionately unable to access benefits, and the population at large. In addition, a lack of administrative capacity on the part of many municipalities has further complicated government attempts at reform and arguably added to public scepticism regarding the feasibility of a minimum income programme.

The claimed impact of late home leaving and perceived administrative difficulties was then supported via an analysis of Italian and cross-national survey data from 1999. The latter 
approach employed multi-level model analysis to test the theory on a sample of 12 European countries. Results suggested the applicability of most of the factors discussed in the FrenchItalian comparison, although the impact of late home leaving was only apparent at the level of the broader public. Although we also considered the potential impact of the size of the informal economy, it did not have a robust effect; that said, high correlations between the variable and both poverty reduction and home leaving ages prevent us from drawing strong conclusions on this point.

Ultimately, we arrive at point where we must theorize about a dog that did not bark. It is obvious that the structure of the Italian welfare state (among others) creates a rather large group of individuals in typical employment who do well by the skewed nature of unemployment benefits. That neither they nor most of the unions that represent so many of them press the government to reform the system is no surprise. But the historic lack of popular pressure from the large number of individuals broadly excluded from coverage is indeed peculiar. To explain this situation, it has been suggested that certain characteristically "Southern European" attributes have diminished calls for reform. The result is thus a level of popular discontent with the current system that is lower than might otherwise be expected. Central to these conclusions is an implicit argument that while public opinion helps shape welfare states, welfare states also shape preferences (see Brooks and Manza, 2007; Soroka and Wlezien, 2010).

There are a few signs of hope for the future, however. Faced with persistent high unemployment (especially among youths) and poverty rates since the start of the Eurozone crisis, some public attention has recently shifted back to the failed project. This culminated with a signature collecting campaign for the institution of a minimum income-style programme submitting over 50000 signatures to Parliament in April 2013. Subsequently, the Grand Coalition government introduced a restricted minimum income-style project in the 2014 Legge 
di stabilità ("[Financial] Stability Legislation"), enacted as a limited anti-poverty measure (lasting three years and implemented only in a few major metropolitan areas). Yet this temporary, limited measure far from necessarily spells the beginning of a move to permanently institute a minimum income scheme. What the future holds for the project therefore remains quite unclear, especially once the Eurozone Crisis passes. In light of past experiences, public attention may well fade with a return of the economic status quo ante.

\section{Appendix}

Countries included in statistical analysis, with sample size.

\begin{tabular}{lc}
\hline Country & Sample Size \\
\hline Austria & 1104 \\
Belgium & 1386 \\
Finland & 823 \\
France & 1210 \\
Germany & 1343
\end{tabular}


Ireland

Italy

Netherlands

Portugal

628

Spain

714

Great Britain

\section{References}

Accordo Interconfederale. (2002). 'Patto Per L'italia - Contratto Per Il Lavoro - Intesa Per La Competitività E L'inclusione Sociale.’ Accessed online at: http://www.confetra.it/it/prontuari/PattoItalia-2002.pdf

Baglioni, S, Della Porta, D. and Graziano P. (2008) 'The Contentious Politics of Unemployment: The Italian Case in Comparative Perspective.' European Journal of Political Research 47: 827851.

Barbier, J-C. and Fargion, V. (2004) 'Continental Inconsistencies on the Path to Activation: Consequences for Social Citizenship in Italy and France.' European Societies 6: 437-460.

Barbier, J-C. and Théret B. (2001) Welfare-to-Work or Work-to-Welfare. In: Gilbert N and Van Voorhis R (eds) Activating the unemployed: A comparative appraisal of work-oriented policies. New Brunswick, NJ: Transaction Publishers, 135-184.

Bec C. (1995) 'Assistance and equality in the French social welfare system.' In D. Bouget B. and Palier (eds) Comparing social welfare systems in Nordic Europe and France. Paris, France: MIRE-DREES, 127-139. 
Béland, D. and Hansen, R. (2000) 'Reforming the French Welfare State: Solidarity, Social Exclusion and the Three Crises of Citizenship.' West European Politics 23: 47-64.

Belorgey, J-M. (1988) La gauche et les pauvres, Paris, France: Syros.

Bentolila, S. and Ichino, A. (2001) 'Unemployment and Consumption near and Far Away from the Mediterranean? '. Journal of Population Economics 21: 255-80.

Berton, F., Richiardi, M. and Sacchi, S. (2009) 'Flessibilità Del Lavoro E Precarietà Dei Lavoratori in Italia: Analisi Empiriche E Proposte Di Policy.' Rivista Italiana di Politche Pubbliche: 33-70.

Blekesaune, M. and Quadagno, J. (2003) 'Public Attitudes toward Welfare State Policies: A Comparative Analysis of 24 Nations.' European Sociological Review 19: 415-27.

Bonoli, G. and Haüsermann, S. (2009) 'Who Wants What from the Welfare State? Socio-Structural Cleavages in Distributional Politics: Evidence from Swiss Referendum Votes.' European Societies 11: 211-32.

Brooks, C. and Manza, J. (2007) Why Welfare States Persist: The Importance of Public Opinion in Democracies. Chicago, IL: The University of Chicago Press.

Burgoon, B., and Dekker, F. (2010) 'Flexible Employment, Economic Insecurity and Social Policy Preferences in Europe.' Journal of European Social Policy 20: 126-41.

Castles, F. G. (2004) The Future of the Welfare State: Crisis Myths and Crisis Realities. Oxford, UK: Oxford University Press.

Clegg, D. (2010) 'From Insurance or Insertion to Rights and Responsibilities: The Shifting Logics of Unemployment Policy in France.' In A. Neville (ed.) Human Rights and Social Policy: A Comparative Analysis of Values and Citizenship in Oecd Countries. Cheltenham, UK: Edward Elgar. 83-100.

Davidsson, J. B. and Emmenegger, P. (2012) 'Defending the Organisation, Not the Members: Unions and the Reform of Job Security Legislation in Western Europe.' European Journal of Political Research: 1-25.

Dell'Aringa, C. and Lodovici, M. S. (1996) 'Policies for the Unemployed and Social Shock Absorbers: The Italian Experience.' South European Society and Politics 1: 172-97.

Emmenegger, P. (2009) 'Barriers to Entry: Insider/Outsider Politics and the Political Determinants of Job Security Regulations.' Journal of European Social Policy 19: 131-46.

Eurostat. (2009) 'Youth In Europe - A statistical portrait'. Luxembourg: Publications Office of the European Union.

. (2010) 'Household Structure in the EU'. Luxembourg: Publications Office of the European Union.

. (2012) 'Income and Living Conditions Dataset.' ed. Eurostat. Luxembourg.

EVS. (2011a) 'European Values Study 1999 - Integrated Dataset.' Cologne, Germany: GESIS Data Archive.

. (2011b) 'European Values Study 2008 - Integrated Dataset.' Cologne, Germany: GESIS Data Archive.

Fargion, V. (2003) 'Half Way through the Ford: The Italian Welfare State at the Start of the New Century.' In N. Gilbert and R. A. Van Voorhis (eds.) Changing Patterns of Social Protection. New Brunswick, NJ: Transaction Publishers. 309-38.

Ferrera, M. (1996) 'The 'Southern Model' of Welfare in Social Europe.' Journal of European Social Policy 6: 17-37.

. (2000) 'Reconstructing the Welfare State in Southern Europe.' In S. Kuhnle (ed.) Survival of the European Welfare State. London, UK: Routledge. 166-81.

. (2005) 'Welfare States and Social Safety Nets in Southern Europe: An Introduction.' In M. Ferrera (ed.) Welfare State Reform in Southern Europe: Fighting Poverty and Social Exclusion in Italy, Spain, Portugal and Greece. New York City, NY: Routledge. 1-32.

Garrett, G. (1998) Partisan Politics in the Global Economy. New York, NY: Cambridge University Press.

Gough, I. (1996) 'Social Assistance in Southern Europe.' South European Society and Politics 1: 123.

Graziano, P. and Jessoula, M. (2011) 'Eppur Si Muoveva...' the Italian Trajectory of Recent Welfare Reforms: From 'Rescued by Europe' to Euro-Scepticism.' In P. Graziano, S. Jacquot and B 
Palier (eds.) The EU and the Domestic Politics of Welfare State Reforms: Europa, Europae.

Basingstoke, UK: Palgrave Macmillan. 148-74.

Iacovou, M. (2011) 'Leaving Home: Independence, Togetherness and Income in Europe.' Department of Economic and Social Affairs United Nations (Population Division), Expert Paper No. 2011/10

ISSP Research Group, International Social Survey Programme (ISSP). (1985) 'Role of Government I, 1985.' Cologne, Germany: GESIS.

. (1990) 'Role of Government II, 1990.' Cologne, Germany: GESIS.

. (1996) 'Role of Government III, 1996.' Cologne, Germany: GESIS.

LIS. (2013) 'Luxembourg Income Study Database (LIS), www.lisdatacenter.org (Multiple Countries); 1998-2001.' Luxembourg.

Matsaganis, M., Maurizio F., Luis C. and Moreno, L. (2003) 'Mending Nets in the South: AntiPoverty Policies in Greece, Italy, Portugal and Spain.' Social Policy \& Administration 37: 639-55.

Milio, S. (2007) 'Can Administrative Capacity Explain Differences in Regional Performances?:

Evidence from Structural Funds Implementation in Southern Italy.' Regional Studies 41: 42942.

Ministero del Lavoro e delle Politiche Sociali. (2003) 'Piano Di Azione Nazionale Contro La Povertà E L'esclusione Sociale 2003-2005.' Rome, Italy. Accessed online at http://db.formez.it/StoricoArchivioNews.nsf/a26f42aa355bd33dc1256ebc003de13e/5535745a dfd9d78dc1256d900058541e? OpenDocument

Mitterrand, F. (1988) 'Lettre À Tous Les Français.' Libération, 7 April.

Naldini, M. (2003) The Family in the Mediterranean Welfare State. London, UK: Frank Cass

Norwegian Social Science Data Services - Data Archive and distributor of ESS data. (2008) 'ESS Round 4: European Social Survey Round 4 Data.' Norway.

OECD. (2011) 'OECD Employment and Labour Market Statistics'.

Palier, B. (2004) 'French Welfare Reform in Comparative Perspective.' Revue Française des Affaires Sociales 45: 97-124.

Palier, B. and Thelen, K. (2010) 'Institutionalizing Dualism: Complementarities and Change in France and Germany.' Politics \& Society 38: 119-48.

Paugam, S. (1993) La Société Française Et Ses Pauvres: L'expérience Du Revenu Minimum D'insertion. Paris, France: Presses Universitaires de France.

Pfeifer, M. (2009) 'Public Opinion on State Responsibility for Minimum Income Protection: A Comparison of 14 European Countries.' Acta Sociologica 52: 117-34.

Putnam, R. (1993) Making Democracy Work: Civic Traditions in Modern Italy. Princeton, NJ: Princeton University Press.

Rueda, D. (2007) Social Democracy inside Out: Partisanship and Labor Market Policy in Industrialised Democracies. New York, NY: Oxford University Press.

Sacchi, S. and Bastagli, F. (2005) 'Italy - Striving Uphill but Stopping Halfway: The Troubled Journey of the Experimental Minimum Insertion Income.' In M. Ferrera (ed.) Welfare State Reform in Southern Europe: Fighting Poverty and Social Exclusion in Italy, Spain, Portugal and Greece. New York, NY: Routledge. 84-140.

Schneider, F. (2005) 'Shadow Economies around the World: What Do We Really Know?'. European Journal of Political Economy 21: 598-642.

Schneider F., Buehn A. and Montenegro C. E. (2010) 'Shadow Economies All over the World: New Estimates for 162 Countries from 1999 to 2007.' Policy Research Working Paper.

Silver, H. (1994) 'Social Exclusion and Social Solidarity: Three Paradigms.' International Labour Review 133: 531-78.

Soroka, S. N. and Wlezien, C. (2010) Degrees of Democracy: Politics, Public Opinion, and Policy. New York, NY: Cambridge University Press.

Taylor-Gooby, P. (2011) 'Does Risk Society Erode Welfare State Solidarity?'. Policy \& Politics 39: 147-61.

Van Oorschot, W. (2006) 'Making the Difference in Social Europe: Deservingness Perceptions among Citizens of European Welfare States.' Journal of European Social Policy 16: 23-42. 
Figure 1: 


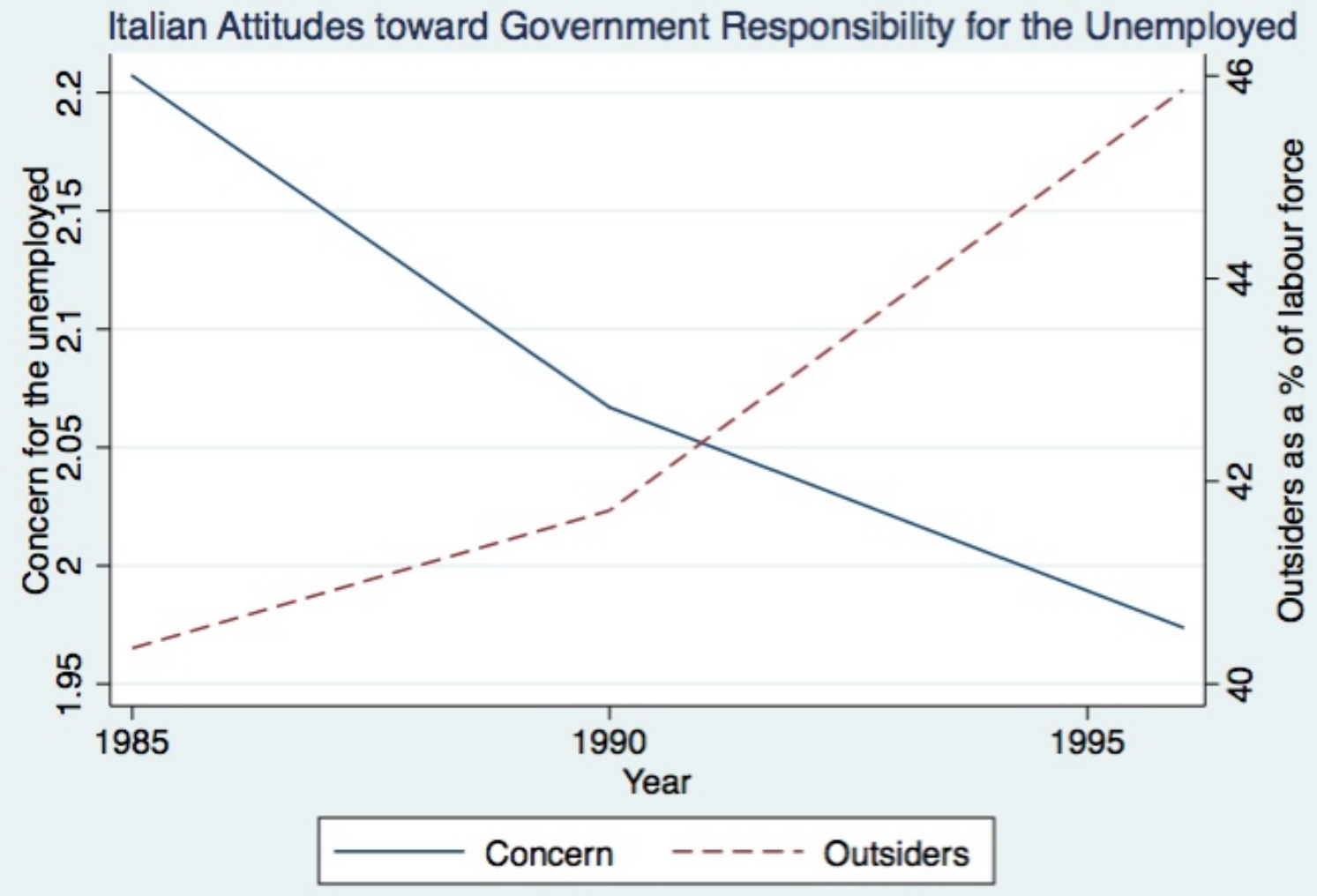

Source: ISSP (1985); (1990); (1996); OECD Labour Market Statistics (2011); Eurostat (2014)

Table 1: 


\begin{tabular}{|c|c|c|}
\hline Independent Variables & Italy & France \\
\hline Youth living in parental home & $-.061^{* * *}$ & -.055 \\
\hline & $(.017)$ & $(.033)$ \\
\hline Youth outside of parental home & -.017 & $-.052^{* *}$ \\
\hline & $(.019)$ & $(.020)$ \\
\hline Unemployed & .066 & $.127^{* *}$ \\
\hline & $(.058)$ & $(.038)$ \\
\hline Parental Home \& Unemployed & .051 & -.011 \\
\hline Interaction & $(.067)$ & $(.102)$ \\
\hline Belief in Increasing Municipal Power & .025 &. $\mathbf{0 3 3}^{+}$ \\
\hline & $(.016)$ & $(.020)$ \\
\hline Full-time Employment & $-.040^{*}$ & -.029 \\
\hline & $(.019)$ & $(.025)$ \\
\hline Part-time Employment & -.018 & -.012 \\
\hline & $(.025)$ & $(.036)$ \\
\hline Self-Employment & $-.053^{*}$ & .008 \\
\hline & $(.025)$ & $(.058)$ \\
\hline Family Income & -.019 & -.011 \\
\hline & $(.016)$ & $(.024)$ \\
\hline Male & -.007 & -.021 \\
\hline & $(.013)$ & $(.017)$ \\
\hline Education Level & .022 & $.052^{*}$ \\
\hline & $(.018)$ & $(.020)$ \\
\hline Retiree & -.001 & .040 \\
\hline & $(.021)$ & $(.029)$ \\
\hline Constant & .686 & .626 \\
\hline & $(.020)$ & $(.030)$ \\
\hline
\end{tabular}




\begin{tabular}{lcc}
\hline$N$ & 1360 & 1210 \\
$R^{2}$ & .034 & .042
\end{tabular}

Note: Cells contain OLS linear regression coefficients with standard errors italicized in parentheses. Coefficients that reach $(\mathrm{p}<.05)$ or almost reach $(\mathrm{p}<.10)$ significance are bolded.

$+\mathrm{p}<.10, * \mathrm{p}<.05, * * \mathrm{p}<.01, * * * \mathrm{p}<.001$

Source: EVS-1999 Data (2011a). 
Table 2:

\begin{tabular}{|c|c|c|c|}
\hline \multicolumn{4}{|c|}{ Concern for the living conditions of the unemployed - 12 country multilevel model analysis ${ }^{14}$} \\
\hline Independent Variables & Model 1 & Model 2 & Model 3 \\
\hline \multirow[t]{2}{*}{ Youth living in parental home } & $-.052^{* * * *}$ & $-.051^{* * *}$ & $-.054^{* * *}$ \\
\hline & $(.008)$ & $(.008)$ & $(.008)$ \\
\hline Youth outside of parental & $-.050^{* * * *}$ & $-.051^{* * *}$ & $-.049^{* * * *}$ \\
\hline home & $(.006)$ & $(.006)$ & $(.006)$ \\
\hline \multirow[t]{2}{*}{ Unemployed } & $.087^{* * *}$ & $.085^{* * *}$ & $.085^{* * *}$ \\
\hline & $(.011)$ & $(.011)$ & $(.011)$ \\
\hline Parental Home \& Unemployed & $-.049^{*}$ & $-.047^{+}$ & $-.044^{+}$ \\
\hline Interaction & $(.024)$ & $(.024)$ & $(.024)$ \\
\hline Increase & $.038^{* * *}$ & $.038^{* * *}$ & $.033^{* * *}$ \\
\hline Municipal Power & $(.005)$ & $(.005)$ & $(.005)$ \\
\hline \multirow[t]{2}{*}{ Full-time Employment } & $-.025^{* * *}$ & $-.024^{* * * *}$ & $-.025^{* * * *}$ \\
\hline & $(.007)$ & $(.007)$ & $(.007)$ \\
\hline \multirow[t]{2}{*}{ Part-time Employment } & -.015 & -.011 & -.009 \\
\hline & $(.009)$ & $(.009)$ & $(.009)$ \\
\hline \multirow[t]{2}{*}{ Self-Employment } & $-.026^{*}$ & $-.022^{*}$ & $-.022^{*}$ \\
\hline & $(.011)$ & $(.011)$ & $(.011)$ \\
\hline \multirow[t]{2}{*}{ Family Income } & -.006 & -0.005 & -.005 \\
\hline & $(.006)$ & $(.006)$ & $(.006)$ \\
\hline \multirow[t]{2}{*}{ Male } & $-.008^{+}$ & $-.009^{+}$ & $-.009^{+}$ \\
\hline & $(.005)$ & $(.005)$ & $(.005)$ \\
\hline \multirow[t]{2}{*}{ Education Level } & .007 & .007 & .010 \\
\hline & $(.006)$ & $(.006)$ & $(.006)$ \\
\hline \multirow[t]{2}{*}{ Retiree } & $.018^{*}$ & $.019^{*}$ & $.019^{*}$ \\
\hline & $(.007)$ & $(.007)$ & $(.007)$ \\
\hline \multirow[t]{2}{*}{ Poverty Reduction } & $-.011^{* * *}$ & $-.009^{* * * *}$ & $-.478^{* * *}$ \\
\hline & $(.001)$ & $(.001)$ & $(.052)$ \\
\hline Median Age of & --- & -- & $-.210^{* * * *}$ \\
\hline
\end{tabular}


Home Leaving \& Poverty

Reduction Interaction

Size of the Informal

$--$

$.065^{* * *}$

Economy

(.008)

Informal Economy \& Poverty

$--$

$-.006^{* * *}$

Reduction Interaction

$(.001)$

Mean Unemployment

$--$

$.004^{* * *}$

$\mathbf{0 . 0 0 3}^{* *}$

(1997-1999)

$(.001)$

(.001)

$\Delta$ GDP

$8.57 \mathrm{e}-08$

$-1.91 \mathrm{e}-08$

(1.02e-07)

$(1.24 e-07)$

Constant

$.692^{* * *}$

$.642^{* * *}$

$4.953^{* * *}$

(.013)

(.013)

$(.482)$

N Observations

11745

11745

11745

N Groups

12

12

12

$R^{2}$-within

.027

.027

.028

$R^{2}$-between

.467

.499

.611

Note: Cells contain GLS random-effects regression coefficients (with standard errors italicized in parentheses. Coefficients that reach $(\mathrm{p}<.05)$ or almost reach $(\mathrm{p}<.10)$ significance are bolded.

$+\mathrm{p}<.10, * \mathrm{p}<.05, * * \mathrm{p}<.01, * * * \mathrm{p}<.001$

Source: EVS-1999 Data (2011a).

(1) Although some local level minimum income schemes have long been in existence, their presence is far from ubiquitous and the benefits are quite variable in their generosity.

(2) Pro-minimum income positions were espoused during a series of interviews at various left/centreleft parties, including the Partito Democratico.

(3) Interviews at the Confederazione Generale Italiana del Lavoro suggested that even they, the only major confederation not to sigh the Pact, were critical of the implementation of the minimum income experiment (despite interest in the programme as an anti-poverty instrument).

(4) Two-tailed tests suggest that the differences between the means are statistically significant. The number of observations in 1985, 1990, and 1996 were 1528, 964, and 1048 respectively. 
(5) Due to data limitations, values are calculated with different denominators: part-time labour is a \% of total employment; temporary employment is a $\%$ of dependent employment; and long-term unemployment (over 12 months) is a \% of the civilian labour force. Nevertheless, the values are adequate for our purposes and are indicative of the general increase.

(6) Interviews at the Partito Democratico suggested that this position is held even within the party.

(7) $2002 / 2003$ estimates.

(8) Since the design of the relevant survey question does not allow one to distinguish adult children living in their parent's home from those who have brought their parent into their own home, a cut-off age of 35 (given a median home-leaving age of about 30) was chosen to prevent the likelihood of the latter possibility affecting the results.

(9) Combined with retirees, it completes the controls for age (with three brackets, 15-35, 36-64, and $64+)$.

(10) Data from Eurostat (2010) - though data limitations restrict us to data from 2007. Nevertheless, a comparison of median home leaving ages in the 1980s with those in the 2000s reveals relatively stable ordering, giving us good reason to believe that the values can reasonably be expected to reflect those in 1999. In addition, using the mean of the two values (while this forces us to drop two cases) does not have a notable impact on the results, with only small changes to the coefficients.

(11) Data for 1999 from Schneider et al. (2010).

(12) Alternatively, mean GDP from the 1997-1999 period was used in lieu of change in GDP, but there was no notable difference in the results.

(13) The only correlations that surpass 0.1 are between median home leaving and living in the parental home (0.16), median home leaving and education levels (-0.11), and the size of the informal economy and living in the parental home (0.12).

(14) See Appendix for cases and sample sizes. 